\title{
A LETTER FROM THE GOVERNOR OF BIG BLUE MARBLE SCHOOL FOR MORAL URGENCY, SOUL MAKING AND HUMAN ADVANCEMENTS Tim Fisher
}

\begin{abstract}
A traditional defense of God in the face of pain and suffering is that humans learn from encounters with suffering - learn something wonderfully valuable that could not be learned in any other way. God is a teacher, and we humans are the students. This article examines the Problem of Evil through this paradigm. It argues that any God-as-teacher defense of evil fails on its face because God does not meet even the most lax standard for teacher behavior and action.
\end{abstract}

Dear Humanity,

I write to you in my capacity as Chair of the Governors of Big Blue Marble School for Moral Urgency, Soul Making and Human Advancements.

As many of you are aware, we have recently overhauled our curriculum and re-assessed our teaching needs. As a result, I can now confirm that long-time teacher, God, has been sacked.

God was the sole founder of Big Blue Marble some 5 billion years ago. Although it took, well, almost 5 billion years before the first of you humans started attending lessons, God soon became a much-loved teacher. Those first lessons were not easy. We remember the scandal of Adam and Eve, the wet-mess of the Ark project, and that confusing Reformation business. But it was God who wrote our school's mission statement; a set of beliefs we continue to hold dear: 'To show humanity it is loved and to grown humanity into God-loving, virtuous, and harmonious creatures through a process of soul maturation.' 
The Governors understand that God's sacking will upset many of you. They have asked me to write and explain in detail the 10 reasons why we have made this decision.

We owe you that.

\section{The Governors agree that God's teaching methods are} horrific, and almost theatrically over the top

God is the best teacher around. No question. He can literally do ANYTHING. He can get humans to learn ANYTHING by manipulating the learning environment in ANY WAY he wants and by using ANY method he likes. You can therefore imagine my horror and surprise when, upon entering God's classroom last week, I found students running from typhoons, fighting over inadequate food, falling from cliffs, and trying to escape the bite of a hungry tiger.

'Oh, have no fear Governor', said God in response to my horror at seeing a legless, very dead child. 'They are learning about love and compassion and charity.'

'Couldn't you have them learn those things by reading a book? Or by frolicking with sheep? Or learn from getting just a small scratch?' I asked.

'Oh, of course, I could do that', said God. 'After all, I AM God. But this pain-and-suffering method works well - at least for those who survive.'

Shocking, I think you'll agree. Especially given God's continuing insistence on his limitless and unquenchable love for you all.

\section{The Governors agree that God could have done more with the Better Human Learner Program}

Ok, I can already hear some of you defending God.

'It's OUR fault', you are saying. 'We cannot learn unless we experience pain and suffering.' 
Perhaps.

But part of the job description for teachers at Big Blue Marble is the modification of the next generation of students so that they are better able to learn. I mean that literally of course - every now and again we manipulate the DNA of you humans so that you can learn things in different, more efficient ways. I remember that God was awfully frustrated his first years when trying to teach you humans, before he dabbled a bit in your evolution to increase your brain size. But the Governors have run out of patience. God simply refused when he first made humans, and has refused ever since, to allow you to learn without the painand-suffering method He so likes.

God likes to blame students when they do not learn. He continues to insist that you humans only learn by the painand-suffering method. But surely He could have made you all able to learn in any way he likes. He is God, after all.

\section{The Governors agree that the passing rate for humans in God's class in unacceptably low}

It is no secret that percentage enrollment numbers to our graduate program, Heaven, are down. It was not so long ago that many more of you humans went on to that eternal program after, er, graduation. But numbers have dwindled and we cannot help but blame God - after all, he is your teacher.

And, of course, we are not just talking about numbers into Heaven. We - the Governors - are ashamed by the number of humans who are not learning the key values we set out in our mission statement. Think about it. I bet you all know people who commit crimes, who have no compassion, who are selfish and greedy and unkind ... who, basically, show no maturing in their soul.

If God cannot get more of you to do these things then is $\mathrm{He}$ really qualified to teach you? Is He really justified in using the pain-and-suffering method? We think not. Despite the numbers, God still claims that pain-and-suffering is the 
best way to teach you all. But - clearly - that method it is not working.

Indeed, we have come to conclude that God no longer knows the difference between educational pain-and-suffering and gratuitous pain-and-suffering. Sad.

\section{The Governors agree that God's F grades are a little} on the harsh side

A young student at Big Blue Marble - a smiley boy called little Rajiv Patel - came to an unsavory and premature end last week. I am sure you all heard. He was struck by lightning. Rajiv's baby status means that he had not completed many classes at Big Blue Marble. How could he have done? It therefore not surprising - but surely no fault of his - that he had not yet learned to love God. But God flunked him anyway - and we all know what an ' $F$ ' grade means in God's class. Fire. Torment.

The Governors believe that Rajiv's failing grade is not his fault. We say, in no small part, it is fault of his teacher. Especially since the bolt of lightning was part of God's lesson plan that day.

\section{The Governors agree that it is no longer acceptable} (1) for God to take out the failings of the first class on the current classes

Yes, Adam and Eve were troublemakers. The rule about the apple and the serpent and all that were perfectly fair rules. We acknowledge that. And yes, Adam and Eve deserved their punishment.

But that was a long time ago.

Why it is that God has not gotten over their disobedience we don't know. But what we do know it that it seems unfair for Him to punish every new class for what happened centuries ago. But He does. 
The Governors agree that it is no longer acceptable for God to play favorites and discriminate among humans

There was a time when the Governors believed God was doing his best to teach all his students equally. We took it for granted in fact.

But we were wrong.

There are some classrooms in which he never even bothers to make announcements. There are some students who don't even know His name. And yet these students still have to experience God's pain-and-suffering method. This seems unfair.

The Governors agree that God has failed to give adequate explanation for his methods

Last week, in God's class, apparently as part of his lesson, I saw a tree fall on a family enjoying a picnic. Three of the four family members died. The surviving member the teenage daughter - asked God very clearly why her mum and dad and brother had to die.

'Trust in my methods', God said. 'All will be well in the end.' (Well, actually, he did not tell the poor girl that at all. $\mathrm{He}$ did his usual thing of communicating with his students only through encrypted bush burnings, visions and dreams.) Anyway, I digress. The point is that no student should have to guess the purpose of a lesson.

Transparency is what we want.

God has moved in mysterious ways for too long.

The Governors believe that God is no longer adequately dealing with troublesome students

Ok, yes, we all know what we mean here - Beelzebub Diablo. Most of you know that he has never been allowed 
to graduate from Big Blue Marble because of the 'incident' all that time ago. Now he spends his days bullying and otherwise causing trouble for students. The Board knows this. We have repeatedly asked God to sort Diablo out, but He has not. Only last school year we had 4000 humans end their lives because Diablo whispered something tempting in their ears.

We have come to believe either God cannot control Diablo, or will not - maybe He enjoys the torment he causes among students. Either way, this is not acceptable at a school that prides itself on the love shown to all students.

\section{The Governors believe that God is hiding behind a false sense of human freedom}

God has long maintained that the pain-and-suffering in his teaching method is, in reality, only the result of you humans abusing the freedom he gives you in the classroom.

'If I step in and stop them hurting one another, they will not learn', He has told me.

'Stopping them hurt one another is counter-productive and negates our entire mission statement', He said.

But God has not been able to explain to the satisfaction of the Governors why this is so. Why do you humans need to be free in this way in order to learn?

'We don't allow students the freedom to fly', I have said. 'We don't allow students the freedom to redo parts of their lives they have messed up.'

We no longer understand why God's conception of freedom for humans includes freedom to hurt each other but does not include other freedoms.

God could have made his classroom in any way he liked. Why not a restriction on (at the very least) acts of extreme violence? Moreover, other teachers stop students who make bad choices before they cause pain. Somehow God thinks this is cheating. We are unsure why. 
(Of course, even if the Guardians could be convinced that human freedom requires the ability to cause pain and harm, that doesn't explain God's penchant for floods, earthquakes, disease and animal attacks in his lesson.) And speaking of animals ...

The Board very much frowns upon the suffering of billions on non-human animals

Every class God runs involves huge quantities of suffering for non-human animals. Given that non-human animals are not even enrolled in the school program, this seems grotesque and pointless.

For these reasons God will no longer be your teacher,

Sincerely,

Chair of the Board of Governors

Tim Fisher teaches philosophy to students ranging from 7 years old to college undergraduates. His primary job is a teacher at Spartanburg Day School in Spartanburg, SC, where he teaches history and philosophy to high school students. He is also philosophy teacher at Wofford College, Spartanburg SC, and runs a Philosophy Club for lower school children at Spartanburg Day School.Tim.Fisher@ Sdsgriffin.Org 